\title{
The nation
}

The powerful but elusive concept of the nation is investigated here. It is distinguished from the 'state' and the relationship between them is examined. Other elements which make the nation are considered, such as religion, language, government, cultural and historical ties, and finally the subjective but still important 'sense of nationhood'. There is also an analysis of contemporary Britain as a nation. Perhaps more accurately the United Kingdom should be considered as a 'state' made up of several 'nations', each of which is discussed in turn. This problem of nation and national identity can be investigated through a study of Northern Ireland, where issues of national and state identity have contributed to the political crisis.

\section{POINTS TO CONSIDER}

- How do the 'state' and the 'nation' differ?

- Are the state and the nation always linked in some way?

- To what extent do race, language, religion, government and shared culture and history shape nations? How do these factors vary from nation to nation?

- Is a 'sense of nationhood' a purely subjective thing?

> How far does a sense of nationhood exist in England, Wales and Scotland? In what ways does this sense, if it exists, manifest itself within modern British society?

> Is the sense of nationhood a valuable and useful concept in explaining the politics of Northern Ireland? 
A nation is a group of people linked together by a common error about their ancestry and a common dislike of their neighbours. (Karl Deutsch, Nationalism and Social Communications, 1953)

The great nations have always acted like gangsters and the small nations like prostitutes. (Stanley Kubrick, 1963)

A nation may be said to consist of its territory, its people, and its laws. The territory is the only part which is of certain durability. (Abraham Lincoln, message to Congress, 1st December 1862)

Many powerful concepts and ideologies have motivated humans. It is difficult to identify a concept more powerful in shaping political activity than the 'nation', or any ideology that motivates people to greater sacrifices or crimes than that of nationalism. Some political movements, such as conservatism and fascism, strongly identify with the nation and are greatly influenced by nationalism. Other movements claim to place the individual at the centre of political activity, as in liberalism, or class, as in socialism, but even these have found that national 'characteristics' greatly influence - indeed, determine - the form in which their ideologies are expressed.

Nevertheless, it is difficult to define the 'nation'. As with the concept of the state, one has an idea as to its meaning that swiftly disintegrates when one attempts to analyse or define it. The state and the nation are not identical, even though the two terms are often used interchangeably by politicians, historians and political scientists. The state is, remember, a legal entity that is directed by a government. The nation, on the other hand, may or may not be closely associated with the state. A nation is composed of a people that share certain characteristics and have a sense of belonging to that nation.

So powerful is the concept of nations as fundamental units of human organisation that international organisations rarely talk of them as being made up of states, which is what they are, and they are usually described in such terms as the League of Nations and the United Nations.

The concept of the 'nation' will be discussed here, first in general terms and then in relation to the nations of the United Kingdom.

\section{The nation}

The concept of the nation developed in Western Europe during the postReformation struggles of the sixteen and seventeenth centuries, and was further shaped by the industrial and political revolutions of the eighteenth and nineteenth centuries. During the nineteenth century, the development of the political power of the middle classes within capitalist states also refined the concept of the nation. The creation of mass democracies and notions of 
popular sovereignty during the twentiety century created the notion of nationality being related to citizenship. Nations and national identity, in the eyes of some commentators, are artificial formulations:

Once you have swallowed the truth that neither our English nor our British identity has their roots in pre-history; once you accept the essential shallowness of nationhood; once you understand that a national identity can be designed in a cynical, professional and calculated way as a life assurance company's corporate personality, you will see why, though our nationhood has fewer certainties, it has fewer shackles too. ${ }^{1}$

Some analysts see 'nations' as modern ideas, largely created by intellectuals and rulers to unite, or fool, the people. Benedict Anderson, in Imagined Communities: Reflections on the Origins and Spread of Nationalism (1983), powerfully argues that nations are 'imagined communities', artificially constructed and sustained, and are not deeply rooted in history or some 'natural' cultural identity. Eric Hobsbawm, in Nations and Nationalism since 1780 (1990), sees nations as constructed around myths of age-old identity and linked to capitalist economic development with the intention of constructing an identity capable of countering the emerging class identity of the proletariat.

Adrian Hastings, in The Construction of Nationhood: Ethnicity, Religion and Nationalism (1997), has argued, however, that one can identify the development of European nations and national identities from the early Middle Ages. Some nations create states as expressions of political nationhood. For Hastings three elements were especially important in the creation of nationhood. War stimulated a sense of national identity and nationalism. The awareness of a wider linguistic sense of identity, rather than dialect, developed as the consequence of writing and the spread of printing. Finally, religion was especially important. The idea of a 'chosen' nation comes from the Old Testament, and kings and national priesthoods used religion to shape national identity.

Friedrich Meinecke, in Cosmopolitanism and the Nation State (1907), distinguished between 'cultural nations' and 'political nations'. Cultural nations are shaped by deep historical, linguistic and ethnic ties that pre-date modern states and may or may not generate demands for political independence. All nations have some elements of 'culture' in their national identity. Examples include the Welsh, the Germans and the Bretons. Political nations, on the other hand, such as the UK and the USA, are bound together by political principles such as 'liberty', 'constitutionalism' and 'the rule of law'. Such principles can come into conflict with other loyalties engendered by 'cultural' national 
identity. Citizens often find cultural national identity more attractive than political national identity.

Ernest Gellner, in Nations and Nationalism (1983), believes that a sense of belonging to a nation, in the cultural sense, is not enough. Nationhood, to have meaning, must be closely associated with the desire for self-government and the creation of state to express that desire.

Thus 'nation' defies a clear definition. Below are some features associated with the nation, identifying both cultural and political aspects of nationhood:

- nation and state;

- race and nation;

- language and the nation;

- religion and national identity;

- government and nation;

- common historical and cultural ties;

- a sense of 'nationhood'.

\section{Nation and state}

Although the term 'nation-state' is a popular one in political science it is one which does not easily help define the concept of the nation. It implies that the vast majority of the population of a territory feels itself as part of a nation and recognises the state as the sovereign power. Indeed, since the concept of 'national self-determination' was announced in 1919 at the Versailles Peace Conference the creation of 'nation-states', as an expression of national identity, has been seen as a political ideal and a desirable objective.

In reality very few 'nation-states' can be identified in any clear sense of the term. One might claim Turkey, Thailand, Japan or Sweden, Denmark, Finland and Norway as constituting examples of this species. But even these might be subject to such qualifications as to cast doubt on the validity of the concept. If one talks of Turkey as a nation-state, for example, then one must ignore the presence of Kurdish, Armenian and other 'national' minorities. The same is true of Belgium, Russia, Spain, Sri Lanka, South Africa and India. All these 'nation-states' have 'national' minorities of various sizes that challenge the actuality of the idea. The political reality is far more complicated, especially as national self-determination can generate dangerous political tensions within a state, potentially leading to its demise.

Most states are in fact multi-national. The United Kingdom, for example, is a multi-national state, consisting of four or five identifiable nations. Attempts to create a 'British' nation and national identity since, say, the union of the English and Scottish crowns in 1603, the union of Scottish and English parliaments in 1707, or the union with Ireland in 1801, have at best been only 
partially successful. Most people within the UK would perceive their national identity as English, Scottish, Welsh, Irish or else some other national or ethnic identity first and British second. Only Loyalists in Northern Ireland define their national identity as solely 'British'.

One needs to distinguish between 'nationality' as an emotional tie with other people of the same 'nation' and 'nationality' as a legal status which may or may not involve a deep emotional identification. Many people have 'British' nationality in the legal sense, but little commitment to British nationality in an emotional sense. The concept of 'citizenship nationality' is often seen as a means by which migrants to the UK can be integrated into national life without giving up their sense of national cultural identity. The concept of legal nationality is often the basis of a strong sense of emotional national identity. For example, the United States has clearly been very successful in encouraging its citizens, many being recent migrants or the children of recent migrants, to develop a strong sense of being 'American' in both legal and emotional terms. At the same time they maintain their sense of ethnic national identity as 'AfricanAmericans', 'Polish-Americans', 'Jewish-Americans', 'Italian-Americans', 'IrishAmericans', and so on.

Many nations, however, are spread over two or more states, as in the case of Koreans, Chinese, Hungarians, Irish, Kurds and Russians. Some of these states may constitute national majorities; in many the nation is a minority, often perceiving itself to be an 'oppressed' national minority. Following the dissolution of the Soviet Union in 1991 an estimated 25 million Russians now live as minorities, often sizeable ones, in new states outside Russia. In some of these states Russians, once associated with the dominant 'imperial' nation, have been subject to discrimination in jobs, education and civil rights. Such national minorities will often appeal to their co-nationals across a state frontier for help, sometimes with dangerous political consequences.

In some cases a nation has no state, not even one which it can share with other nations. Kurds, Armenians, Palestinians all see their national identity as being oppressed, or at least unable to be fully expressed because of the lack of a state. Indeed, it was an article of liberal nationalism in the nineteenth century, and modern nationalism since, that one of the major causes of conflict in the world was the failure of many nations to have a state of their own. Once this was achieved, war, arising from frustrated national identities, would become a thing of the past.

The reality has often been the creation of states that are either too small to be viable economic and political units, or themselves contain disgruntled national minorities that demand further devolution of power, thus weakening the ability of the government to achieve other desirable goals. Oppressive as multi-national states and empires often are, they do 'stop the natives from killing each other' and create a degree of order over large geographical areas. 
In some parts of the world there is no relationship between state and nation. This is especially so in Africa, where the great powers in the late nineteenth century drew the borders of their colonies, and where 'spheres of influence' bore no relation to tribal, linguistic or other deeply rooted social groupings. Western-educated local elites, using Western concepts of the nation, agitated for national independence from the former colonial powers, and sought to create modern nations after leaving a colonial empire. However, they faced considerable difficulties in attempting to overlay, or even replace, traditional and age-old social groupings with stronger emotional ties to the population at large than the 'foreign' concept of the nation. In many cases this led to considerable social tension and, in Biafra, Ethiopia, Katanga, Sudan, Chad, Uganda and elsewhere, violent conflict. However, it is worth noting that, in Africa at least, the very weakness of national identities alternative to the "national identity' associated with the state has ensured that almost all of these states have retained the state frontiers acquired at independence, contrary to widespread fears at the time. One might award much of the credit for this to the role of the state in 'nation-building'.

It is not just in the developing world that the state has played a crucial role in nation-building. A distinction is often made between 'old' nations and 'new' nations. In Europe, or in societies derived from European culture, nations are somehow 'natural' and deeply rooted in ethnic, linguistic or other identity. 'New' nations, usually in Africa and Asia, were 'artificially' created by elites, often somewhat detached from the mass of the population. Here colonial masters imposed the state before a nation existed and the creation of a 'national' identity was, and is, extremely difficult. In Nigeria, for example, there are four main and 245 smaller ethnic groups, and considerable religious, linguistic and regional differences between them.

States thus play a vital role in both old and new nations in creating national identity. 'National' symbols are usually state symbols: flags, anthems, uniforms. The state plays a crucial role in attempting to create a sense of national identity by its educational system, inculcating new generations of citizens with national history, national heroes, national identity and national achievements. It may often identify a national language as the one that all members of the 'nation' should be fluent in. Conscription into the armed forces of the state is often seen as a very important vehicle for encouraging a sense of national identity. This was often used, and still is, as a major justification for the retention of compulsory military service. Indeed, it may even take a civil war to ensure compulsory membership of the nation for disaffected sections of its population (for example, the American Civil War).

Although the state and nation are not the same thing they do play a very important role in shaping one another's identity. Nevertheless, there are many other elements involved in the concept of the nation. 


\section{Race and nation}

During the nineteenth century 'race' and 'nation' were terms used interchangeably. 'Races' peopled Europe: the British race, the German race, the Slav race(s), and so on. Race and nation became so intertwined that they were often used to mean the same thing. Indeed, international politics became, as a consequence of the misapplication of the evolutionary theories of Charles Darwin, a struggle for supremacy and survival among nations. Weak nations were doomed, as 'a law of nature', to come under the thrall of the most powerful nations.

However powerful such theories were, especially by the end of the nineteenth century, they are largely discredited today - except on the fringes of right-wing politics. Science and politics have discredited race-based ideas of national identity.

Science, especially genetics, has demonstrated that human beings form one species (homo sapiens sapiens) and race consists of a set of superficial biological characteristics, (skin colour, hair-type, eye colour) that bears no relationship to cultural characteristics, which are learnt, such as national identity.

Twentieth-century politics saw many bloody conflicts, both international and civil, fought around racial and ethnic identity. In particular, the racial theories of Nazi Germany contributed to the outbreak of the Second World War and were responsible for the mass murder of ethnic groups identified as racially 'inferior' or a threat to 'superior' races. As a consequence of such theories millions of Gypsies, Slavs and, especially, Jews were killed.

Although patently responsible for the bloody nature of conflicts in Bosnia and Kosovo in the 1990s the link between race and nation cannot be sustained in general. Yes, certain biological characteristics are often associated with particular nations. Most Swedes are blond, Italians tend to have darker skins, most Nigerians are black, but these characteristics are shared with peoples who have different national identity. On the other hand, Americans as a nation present themselves with great diversity without claiming race as a defining feature of American national identity.

\section{Language and the nation}

Language is often seized on as being related to national identity. A language expresses the particular experience of a people that constitute a nation. Its words and structure are shaped by and in turn shape the nation. A language carries cultural forms and ideas, expressing national identity. One can hardly imagine English national identity without reference to the impact that the language has had upon it through its literature, especially the works of Shakespeare and Dickens. 
Within the British Isles English was spread as the language of social advancement in the nineteenth century to the detriment - and denigration - of Welsh, Scots Gaelic and Irish. Indeed, the survival of Welsh, Scots Gaelic and Irish Gaelic has become a cause championed by nationalists struggling against English imperialism. Even so, English remains the dominant language spoken in those countries and the Welsh, Scottish and Irish have used the English language to great effect to express aspects of their own national identity.

Nevertheless, while language expresses the cultural identity of a nation it cannot be seen as the same thing as the nation. English is spoken by millions of people in many countries. They may share the language, but would not claim their national identity to be English. Indeed, English (and, for that matter, Spanish, Portuguese and other European languages that are now spoken around the globe as a consequence of European colonial expansion) has developed words and expressions that reflect the experience of the populations of the 'new' nations.

Most nations are, in fact, multi-lingual. Belgium is a small nation deeply divided by language and culture, yet Belgians would not see themselves as French or Dutch. The Swiss have a very strong sense of national identity, yet they have three distinct languages in their country. India has dozens of languages, and this is a factor in inter-communal strife, yet there is still a strong sense of Indian national identity.

\section{Religion and national identity}

Religion is a factor that has played a very important role in the formation of national identity, but one with a mixed relevance today.

Most modern nations in Europe developed out of the collapse of a united Christendom during the early sixteenth century. Prior to that kings and princes fought to establish a degree of independence against the universalist claims of the church. The Protestant Reformation was seized upon by many princes and kings as a means of reinforcing their sovereignty against the papacy. Catholic monarchs at the same time sought to strengthen their political independence of the papacy. The 'Divine Right of Kings', the right to rule being derived from God and not the people, was a doctrine appealing to both Protestant and Catholic monarchs. In fact, adherence to the religious views of the state became a test of loyalty. Individual conscience may have been claimed as a guide for individual Protestants but Protestant states were no more willing to allow freedom of conscience in practice than the Catholic church and Catholic monarchs were.

All across Europe religious identity became closely allied to national identity and was reinforced by the power of the state. English, Welsh and Scottish 
nationhood was closely linked to particular forms of Protestantism developed in their countries. Dutch and Scandinavian national identity was linked to various Protestant churches. Catholicism is closely associated with Italian, Spanish, Portuguese, Croatian, French and Polish national identity, while Russian, Serbian and Greek nationhood is still shaped by Orthodox Christianity.

Religious affiliation was also linked to national identity in the 'new' nations born of European colonial empires. Thus Catholicism is the dominant form of Christianity among the nations of Central and South America, the Philippines and the French population of Quebec. Protestantism has played a key role in creating American identity.

However, the growth of the concept of the sovereignty of the people, first effectively aired by the American and French revolutions of the eighteenth century, was strengthened by the rise of nationalism, the love of the nation, as the new secular 'god' for the people. To man's insignificance before God was now added obeisance towards the nation. Nationalism became, for many, a form of secular religion, with its own heroes, martyrs, worship, creed, and so on. The twentieth century was to witness nationalist wars comparable in destructiveness to the wars of religion in the seventeenth century.

Religion is not integral to national identity solely within the Christian world. Japan with Shintoism, India with Hinduism, Israel with Judaism, Pakistan with Islam, and many other nations are closely identified with religions. Religious beliefs are an essential element in shaping a sense of belonging to a nation for many, probably most, peoples on earth.

Modern nations are multi-religious, even if there is a dominant religion, or they are largely secular. While religious affiliation has an impact on nationhood and identity, one must remember that religions are usually shared across national frontiers. Indeed, religions tend to develop national characteristics. Polish Catholicism, for example, is distinctively Polish. Irish and Italian Catholicism very much reflect aspects of their respective national cultures.

However, religion is only one feature, albeit an important one, in creating a nation.

\section{Government and nation}

Government as an element in influencing national identity is linked to a concept known as 'political nationalism'. National identity, according to political nationalism, is essentially a civic and legal concept that as a consequence does not necessarily stimulate among its citizens deep emotional commitment to the nation concerned. People may choose to join a nation and take on its citizenship without feeling deeply emotionally attached to their new country. 
Nations are often created by particular systems of government, not only, as we have seen, in the conscious creation of a sense of national identity, but they also become closely identified with particular systems of government. American national identity is closely associated with the United States Constitution and liberal democracy. The British, when they think about it at all, see parliamentary democracy as an expression of their national development over the centuries. By the twentieth century nationality in such countries was associated with citizenship, regardless of the people's country of origin or any 'blood ties'. Nationality in this sense became a symbol of a new cultural identity which was shared with or replaced other, older, national identities.

In Eastern Europe in the nineteenth century, nationality was linked to communal groups, based on religion or language, identified as such by the government and with legal political and social status. Often these groups enjoyed a considerable degree of self-government, such as the Jews and Finns had in Imperial Russia, but at the same time they were denied equal citizenship rights and equal legal status before the courts.

The experience of history and the effectiveness of particular types of government system affect the sense of national identity. We have already mentioned the American and British experiences. Russian nationhood has been moulded by experience of strong, powerful, autocratic governments under the tsars and, later, communism as a means of defending the nation against powerful external enemies that threaten the long national frontiers.

National existence depends heavily upon the conditions of power, or lack of it, and political circumstances existing both internally and internationally. Strong governments are better able to strengthen the nation at home and defend its interests abroad. The success or otherwise of a government in achieving its domestic and foreign goals will affect its legitimacy and, as a consequence, the strength and effectiveness of the sense of national identity.

\section{Common historical and cultural ties}

Often connected with the idea of 'cultural nationalism' is the idea that a nation exists because of a shared historical and cultural experience that is different from that of other nations. Anthony Smith, in The Ethnic Origins of Nations (1986), identifies a link between ethnic communities and modern nations, having deep roots in language and history and pre-dating modern political structures. To a great extent this form of nationalism assumes that one can only be born into the nation, and cannot join it. It is often closely associated with the idea that there are deep 'blood ties' between members of an ethnic community.

War has been a major historical element in the creation of modern nations: wars for the expansion of powerful nations, wars for defence, wars to ensure 
the survival of a nation, wars for national liberation. Indeed, it is difficult to find a nation that has not been, in some sense, created and shaped by its experience of war - either as victor or as defeated contestant. English, and later British, nationhood was forged by centuries of war with the French. American identity was forged in the War of Independence. Israel, India, Bangladesh, Pakistan, Vietnam are just a few modern nations created or shaped by the experience of war.

The cultural concept of the nation can be traced back to the writings of the eighteenth-century German philosopher-poet Johann Gottfried Herder, challenging the Enlightenment, rationality, the consequences of the industrial revolution and, especially, the cultural domination of France among the German elite. He conceived the nation in terms of the Volk, a term difficult to translate into English. 'People', the usual translation, is too narrow. The Volk is a vehicle of culture, language, heritage, historical experience, a Volksgeist ('national spirit') shared by a particular people nation - and develops its special genius. Johann Fichte, writing about the same time as Herder, declared that Germany's unique culture could only be defended and enhanced by the political unification of the German people.

Enlightenment

An intellectual movement that began in the late seventeenth century and reached its height in the eighteenth. It exalted reason and challenged the religious and political status quo. The Enlightenment is credited with forming the intellectual underpinning of the French Revolution.

This view of nationhood became very influential during the nineteenth century, both in Germany and elsewhere in Europe. In Italy Guiseppe Mazzini adapted the concept to the nationalist cause, and gave it a liberal 'spin'. He believed that once each nation had its own government there would be peace, both internally and internationally. However, this historical and cultural concept is usually associated with the bitter competitive nationalisms of the late nineteenth century and, especially, Nazism in the 1920s and 1930s. There are modern versions of such views, often connected with far-right and extreme nationalist groups who think they are fighting 'globalisation' and the effects of 'globalised' culture, which are undermining 'authentic' national identity.

\section{A 'sense of nationhood'}

Although it might seem rather circular, a nation is best defined as a group of people who believe themselves to constitute a nation, have things in common with each other and share a sense of nationhood. The nation can be defined as an 'imagined community' where people believe themselves to have some sort of link, or commitment, to others in the nation, most of whom they will never meet. The imagined community also extends into the past. Members of a nation identify with people who lived centuries before and were of the same nation. These other people 'belong' to each other by having the 
same birthplace, and having membership of the same national 'family'. Indeed, the very term has its roots in the Latin nasci, 'to be born', and can be seen when expressed in the terms 'Motherland' or 'Fatherland'. Germans talk of their 'Fatherland', Russians of their 'Motherland' and the British, cosily and curiously, of their 'Homeland'.

A sense of nationhood is clearly associated with loyalty to the nation, the largest political community from which people will accept a claim over all other forms of social loyalty. Betrayal of one's nation is still regarded as one of the greatest crimes, putting at risk one's fellow national members.

\section{Britain and the 'British' nations}

The United Kingdom has great difficulty in being identified as a 'nation-state'. For most of its people there are two competing 'national' identities: 'British', associated with the UK, and 'English', 'Welsh', 'Scottish', and in Northern Ireland 'Loyalist British' and 'Irish'. We will look at these in turn.

\section{Britain}

Britain has an image of being an ancient nation, with its national flag, national anthem, and national governing and other institutions, but in recent years it has been under challenge by other identities. The problem with British nationhood, as with all nations, arises out of its history.

British national identity is closely linked with English national identity and the English national experience. 'British' and 'English' are often used interchangeably by foreigners and by the English themselves (a mistake rarely made by people of the other British nations). This indicates a sense of union of the two national identities in a way that no member of the 'Celtic fringe' (as compared with the English 'centre') would make.

The creation of the United Kingdom is very much the result of England being the dominant power within the British Isles. It has for centuries been the wealthiest country, the most powerful government, and the largest population in these islands. It took centuries of war in Wales and Ireland, and war and economic leverage in Scotland, to establish political union. But it was English power that brought about this union.

After the union of the Scottish and English crowns in 1603, King James I of England (and VI of Scotland) frequently used the term 'British' to describe his new realm. After the union of the English and Scottish parliaments in 1707 the terms 'British' and 'British nation' became increasingly accepted by most people in the Protestant nations of England, Scotland and Wales, and the Protestant 'British' of Ireland; but never so by the Catholic Irish to the same 
degree. Nevertheless, 'British' and 'Britishness' were useful notions for uniting the peoples of the British Isles, who then directed their aggression overseas and created the British Empire. With the development of 'popular' imperialism, associated with the rise of mass democracy, in the late nineteenth century this British national identity established itself as dominant for the peoples of the UK. The wars of the following century strengthened this British national identity, but this configuration did not remain static.

Twenty years after the Second World War almost all the empire had gone. In 1997 Hong Kong was returned to China and the empire was finally laid to rest. Long before then, the strengthening national identities of the constituent nations of Britain were threatening the UK itself.

Nevertheless, one might say there is much life left in the idea of a British national identity. Citizenship is still 'British'. No 'English', 'Scottish' or 'Welsh' national identity exists in domestic or international law. Many - perhaps a majority of - non-white citizens see 'British' as a valuable form of national identity, along civic national lines. English, Scottish and Welsh still have strong ethnic/cultural national connotations. 'Britishness', for 'Black-Britons', 'AsianBritons', and 'Chinese-Britons', may be an intermediate stage before their ultimate national integration as English, Welsh or Scottish.

'Britishness' was created by 250 years of near permanent war with other great powers and within the empire. The UK state was a very effective tool for the potential military power of the British nations. The recent conflicts in the Falklands (1982) and the Gulf (1990-91), and the 'war against terrorism' in Afghanistan and elsewhere, may well strengthen the British sense of national identity.

\section{England}

The close identification of 'England' and 'Britain' often means that insufficient attention is given to English national identity and its distinctiveness from the other nations that constitute Britain.

English nationhood has been shaped by war. Battles and wars of the fifth and sixth centuries determined the very territory of England. The English-Welsh frontier was established long before King Offa of Mercia built his Dyke in the eighth century. The frontier of Scotland moved backwards and forwards for centuries until Elizabeth I's time. Both the Welsh and Scottish borderlands were for centuries wild and violent frontier zones.

Strong regional identities, having deep roots, still exist in this most centralised of nations. Yet England has had a strong centralised state, and with it a concept of national identity, for well over a thousand years. The Norman Conquest took over a very effective state structure and by the thirteenth 
century the Normans and Saxons had fused into an English national identity. This national identity survived civil wars and was greatly strengthened by Tudor monarchs during the sixteenth century and the civil wars and political upheavals of the seventeenth century.

England was shaped by many social developments, especially by being the earliest industrialised nation and an old urbanised nation. There are strong strains of political liberalism and social conservatism running through English culture. The Protestantism of the majority of its population, the Catholicism of a large minority of its people, and its religious toleration all have had a profound influence on the development of England. Modern England is, however, a highly

secular society

A society where religion has no privileged position and is confined to what is presumed to be its rightful non-privileged sphere, as in the United States. Whereas a 'theocratic state' is one in which a particular religion has a special and privileged position, such as Saudi Arabia and Iran.

\section{secular society.}

Immigration and emigration has for centuries moulded English national identity. Empire, economics, politics and overseas colonies encouraged the English to travel and settle widely. These same historical forces were responsible for waves of non- British immigrants over centuries: Jews, Dutch, Germans, Italians, Poles, Ukrainians, Hungarians, Africans, South Asians and Chinese are only some of the major populations that settled in English cities. England is by far the most multi-racial, multi-cultural and multi-religious of the nations of the British Isles.

Some people, especially the English, think there is no such thing as English nationalism. However, many of England's Celtic neighbours think there is, and, moreover, that English nationalism has for centuries oppressed the Welsh, Scots and Irish. Conversely, some English people believe that England actually subsidises Wales and Scotland, for example through over-generous central government grants paid for by English taxpayers.

\section{Scotland}

Scottish identity has been shaped by war, especially against the English; deep regional divisions between Highland and Lowland Scots; religious conflicts between Protestant and Catholic, Presbyterian and Anglican; and rivalries between Glasgow and Edinburgh.

Scotland retained its independence as a consequence of the wars of Robert the Bruce at the start of the fourteenth century. Although Scotland was frequently at war with England over the following two centuries, the English and Scottish crowns were united in 1603 with James VI of Scotland succeeding Elizabeth as James I of England. Nevertheless, Scotland saw little of its Stuart kings and, although playing a crucial role in the mid-seventeenth-century civil wars, 
it retained its own parliament until 1707, when it merged with the Westminster Parliament.

The Act of Union was bitterly resented by many Scots as ending national independence. The accession of the Hanoverians to the British throne in 1714 ended any possibility of peaceful restoration of the Stuart monarchy. The British government, with much Scottish support, crushed Highland rebellions in 1715 and 1745. Emigration from Scotland to England and overseas became a feature of the Scottish national experience. For two hundred years Scots participated in empire-building and the industrial revolution, and in British politics. Scotland retained distinct national institutions: its own legal system, church, local government and education systems; and its banks issued its own paper currency. Few travelling in Scotland for any length of time could be in any doubt that they have entered a country with distinct national characteristics.

By the 1960s the decline of once prosperous Scottish industries - coal, steel, shipbuilding, heavy engineering - and rising unemployment, combined with the discovery of oil, 'Scotland's oil', as nationalists declared it, stimulated demands for greater self-government by the Scottish National Party (SNP).

The SNP, founded in 1934, argued that the major political parties and the Westminster Parliament or the British government did not adequately serve Scotland. Many SNP supporters came from cultural nationalist movements seeking to protect the Gaelic language, Scottish culture and a distinct national identity. The majority, however, came from the Scottish socialist tradition and believed that a progressive, just society could not be created by a Westminster dominated by the English, who often, too often, returned Conservative governments.

The economic crises of the 1970s particularly hit Scotland, with its heavy reliance on declining industries for employment and wealth. The Conservative governments of the 1980s and 1990s, with their electoral roots in England, were regarded as governing Scotland with little legitimacy. Scottish Tories became a very rare political species as national economic policies seemed to be particularly damaging to Scotland. Tory attacks on public housing and public spending particularly hurt Scotland, which had high levels of public-sector employment and was heavily dependent on state support. The introduction of the poll tax in Scotland a year earlier than in England was signally stimulating to Scottish grievances against an 'English' Conservative government.

In the 1990s strong economic growth in Scotland centred on the new IT and service sectors, and the importance of oil to the Scottish economy declined. There was a strong revival of a confident, distinct Scottish cultural identity, as displayed in music, literature and the arts, instead of in the widely derided 
'tartan' identity of kilts, bagpipes, Bonnie Prince Charlie, and so on. Demands for a Scottish parliament to reflect this identity grew. The Conservative Party resisted these demands but Labour and the Liberal Democrats support the implementation of devolution for Scotland. The SNP was somewhat dubious about the merits of a devolved parliament when they argued for an independent Scotland.

In 1997 the Labour Party returned to power with a 'landslide' victory, involving the eradication of Scottish Tory MPs and a strong Scottish presence among leading members of the government. Proposals for a devolved parliament with tax-raising powers were approved by a referendum in 1998 and enacted into law. The first Scottish parliament in nearly three hundred years was elected in 1999 and began work with a joint Labour-Liberal Democrat coalition government.

It was clear that the Scottish Parliament would seek to introduce measures reflecting the more left-wing Scottish political culture rather than the Westminster Labour government. Tuition fees were removed for Scottish university students, and higher levels of financial support for the elderly in care homes and greater levels of health and education spending were introduced.

Whether such forms of self-government will for long satisfy Scottish national identity remains to be seen. Pressures are growing for more powers to be transferred to the Scottish Parliament. The SNP continues to argue that only full independence from the UK and membership of the EU will properly allow Scottish nationhood to be fully expressed. This seems unlikely at present. But one may envisage problems with a Labour-Liberal Democrat Scottish government and a Conservative Westminster government at some future time.

\section{Wales}

Welsh identity, even more than Scottish, has been influenced by military resistance to English domination. Political disunity and relative weakness in medieval Wales encouraged English monarchs to intervene. Centuries of warfare, celebrated in Welsh literature and evidenced by dozens of castles and strongholds, ultimately ended with political union with England and, with the Tudors, the 'Welsh' acquisition of the monarchy in 1485. Since then Wales and the Welsh have played a major, often crucial, role in 'English' history.

Welsh political independence ended centuries ago. Welsh cultural nationalism, however, has been at the core of its identity. One element has been its nonconformist Christian tradition. Also important is the Welsh language. This was a language in decline during the nineteenth century and most of the twentieth. English became the language of the Welsh elite. The industrialisation of South Wales disrupted ancient ways of life and sucked in non-Welsh 
speakers from England and Scotland. Welsh people emigrated to England and overseas. Finally, there was a systematic attempt by the authorities to destroy Welsh as a language of education and government.

Welsh nationalism finds political expression in Plaid Cymru, which was founded in 1925 and which sought rather to defend Welsh culture than seek Welsh independence. Some Welsh activists believed this programme to be too tame. Some thought radical action was needed to defend the language in order to challenge the growth of English-owned second homes and their impact on Welsh culture and house prices; and to push for economic aid to offset the decline of farming, steel, coal and engineering in Wales. A few planted bombs, burnt English second homes and defaced English on road signs, but the defence of Welsh national identity was overwhelmingly peaceful and parliamentary.

By the end of the twentieth century Welsh was no longer in decline and was officially supported in education, government and the media. New industries had been attracted to Wales by UK regional aid programmes and the EU. Nevertheless, Wales remained a nation divided by language and geography. Transport links tend to run from England into Wales, rather than to connect areas within the country, and Welsh remained largely confined to its heartlands in the north and west.

Wales, partly as a consequence of long integration into English politics, has been lukewarm about devolution. The 1979 referendum on devolution returned a 'No' vote. Conservative policies in Wales during the 1980s and 1990s combined simultaneously the run-down of traditional industries and considerable regional aid, as well as support for the Welsh language and culture.

In 1997, however, the Conservative Party was eliminated from Wales in the general election, while the Labour, Liberal Democrat and Plaid Cymru parties were all committed to devolution. However, both in the 1998 referendum and the 1999 elections to the Welsh Assembly turnout was low and interest hard to stimulate, especially as the assembly has no tax-raising powers. After some initial teething problems, most notably over the degree of influence the national Labour Party should have over the leadership of the Welsh Party, the assembly is becoming an effective expansion of Welsh national identity within the UK and the EU.

\section{Northern Ireland}

Northern Ireland is a very peculiar part of the UK in terms of national identity. One might perceive three 'national identities' here: 'British', 'Irish' and 'Northern Irish'. 
'British' is the legal national identity available to all citizens in Northern Ireland. However, for the Protestant population of the province, the descendants of Scottish and English settlers of the early seventeenth century, this is their sole national identity. These people were intended as the rulers of Ireland, a distinct minority defined by their religion and political power, in a largely hostile country. Seething resentment and occasional revolt by the Irish encouraged a 'siege' mentality among these British (sometimes identified also as 'Unionists' or 'Loyalists').

Having once dominated the Irish Parliament until its abolition in 1801, Unionists were hostile to Irish Home Rule as a wider franchise would result in a permanent parliamentary majority for the Catholic Irish. By this time the concept of 'Loyalism' was a feature of Northern Irish 'British' identity. This meant loyalty to the British Crown, their British identity, and the Protestant religion, celebrating the Battle of the Boyne (1690) and other landmarks of Protestant ascendancy in Ireland. By 1910, and the Third Irish Home Rule Bill, Loyalists had armed themselves to resist both the Catholic Irish and the British government with the rallying cry, 'Home Rule is Rome Rule'.

The First World War put Home Rule on hold. But by 1919 the issue had reappeared with a vengeance. An Irish revolt in 1916, and its brutal suppression by the British, produced a majority of Irish MPs for Sinn Fein in the post-war election who refused to go to Westminster and promptly declared an Irish Republic. The subsequent Anglo-Irish War lasted until 1921, when the British Government and the Irish 'government' agreed to the partition of the island into a twenty-six-county Free State and a six-county Northern Ireland remaining within the UK, but with its own 'devolved' government at Stormont Castle.

For sixty years Stormont was an expression of British/Unionist rule in Ireland and Loyalist national identity. Having lost control of Ireland, Loyalists determined not to lose 'Ulster', as they

partition

The division of a nation or state into two or more parts, such as Poland in the eighteenth century, and Ireland, Korea and Cyprus in the twentieth. called the province. Vote-rigging, gerrymandering, job and housing discrimination and Loyalist violence were all used to oppress Catholics and ensure their own community was kept voting for Unionist politicians.

By the late 1960s this policy of control was breaking down into sectarian violence arising out of conflicting national identities. By 1972 the situation had reached such a pass that the UK government ended Stormont and introduced Direct Rule. Attempts at a new devolved parliament, involving powersharing between Catholic and Protestant politicians, broke down in 1974, in the face of Loyalist intransigence, and are at present by no means certain of success as the Northern Ireland Assembly struggles with the competing national identities of the population. 
For many Protestants, British governments over the last thirty years have been seeking to accommodate the Irish population in the North and the Republic at their own expense. Every concession to Catholics is perceived by Loyalists as a threat to the British national identity of the majority population. Restrictions on Loyalist marches (a celebration of their identity), changes in the police service (traditionally dominated by Protestants), and Sinn Fein ministers in the Northern Ireland Executive (men associated with Republican terrorism) are seen as part of a long process of pushing the 'British' people of Northern Ireland into some form of Catholic-dominated political system and, thereby, a betrayal of their services to the Crown and Protestantism over the past four centuries.

Irish national identity is largely, but not entirely, Catholic and Celtic, and shaped by centuries of struggle against English, British and 'Loyalist' domination and oppression in Ireland.

English and, later, British imperialism in Ireland began in the late twelfth century with Edward I. The Elizabethan and Cromwellian conquests of the late sixteenth century and the 1650s left bitter memories for Irish nationalists. Revolt in the 1790s, the Fenians in the nineteenth century and the Easter Rising in 1916 are part of a revolutionary tradition in Irish nationalism which believes the British will only leave Ireland when forced out. Only then might Loyalists identify themselves as 'Irishmen'. Failure and defeat only provided another set of nationalist myths and martyrs for the next round of struggle against the British. Running in tandem with this violent struggle for Irish national independence was the parliamentary strain of Land Reform, Home Rule, and cultural renaissance throughout the nineteenth and twentieth centuries.

This struggle did not cease with Partition, but has continued, sometimes violent, sometimes peaceful, but always facing the power of the British state and the 'British' rulers of Northern Ireland. Partition was declared an 'unnatural division of the island'; a united Ireland is the ultimate expression of Irish national identity for both Catholics and Protestants.

One problem with the aspiration to a united Ireland is that the British and Irish identities in Northern Ireland have less and less in common with those of the Republic and Great Britain. Both are active participants in the EU, a project designed in part to reduce national antagonisms and national identities, and both are modern, secular, prosperous liberal democracies, to which the sectarian nationalism of Northern Ireland appears archaic, socially divisive, oppressive, unsuccessful, repulsive and a drag on economic and social development.

One might perceive Northern Ireland as a 'proto-nation', not quite Irish and not quite British but having a national, cultural and political identity of its own deriving from its unique history. Eighty years of the Northern Ireland state have 
created a social and political environment in which Catholics and Protestants, Irish and British, have more in common with each other and less with the Republic of Ireland and Britain. If this is the case, then Northern Ireland requires unique political and social institutions to reflect this 'proto-nationhood'. Perhaps that is why the Good Friday Agreements have, with all their problems and tensions, come closest to a political settlement in the province which satisfies at least some of the national aspirations of Irish and British.

Some political community corresponding to the nation has existed so long in human history that it is almost impossible to imagine that there might be any alternative to it as a focus of identity and loyalty in the political and cultural world. So strong is nationhood that it is relatively easy to be persuaded how 'natural' the division of the human race into nations is.

Nations and national identity are constantly in flux as social and economic forces work on human societies. However, seemingly strong nations have disappeared during the last century. New nations have appeared, with similar very high levels of identity and emotional resonance for their people. One can see that, however powerful the idea of the nation might be, however likely to continue as a defining feature of human political activity, the particular nation with which people will identify is likely to change considerably during the coming century. Nations in some form are here to stay, although one might question whether the nations of today will exist in their present form by the twenty-second century.

\section{Summary}

Perhaps the most powerful of all political concepts to motivate human beings is that of the 'nation'. But the concept is an elusive one. While the 'nation-state' is a term commonly used, many 'nations' do not have states, and there are states comprised of many nations. Important elements in national identity include language, religion, government and common historical and cultural ties. There are enormous differences, however, in the significance of these factors from nation to nation. Perhaps the most useful way of defining a nation is a subjective one. A nation is what its members feel it is, and they are identified by their deep loyalty to it. Britain illustrates the difficulty of identification of the 'nation'. Historically and to a degree culturally it is composed of at least three nations: England, Scotland and Wales. Northern Ireland further complicates matters by being arguably composed of two nations, Irish and British. Moreover, these two nations are themselves not entirely clear about what precisely their individual national identity is. 


\section{REFERENCES AND FURTHER READING}

1 M. Parris, 'An off-the-peg identity', The Times (7 November 1998).

Alter, P. Nationalism (Edward Arnold, 1989).

Anderson, B. Imagined Communities: Reflections on the Origins and Spread of Nationalism (NLB/Nerso, 1983).

Deutsch, K. Nationalism and Social Communication (Massachusetts

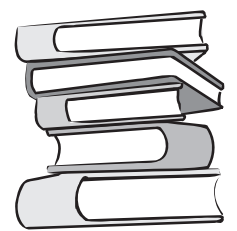
Institute of Technology, 1953).

'Nations and their Past: The Uses and Abuses of History', Economist (21 December 1996), pp. 53-6.

Gellner, E. Nations and Nationalism (Blackwell, 1983).

Hastings, A. The Construction of Nationhood: Ethnicity, Religion and Nationalism

(Cambridge University Press, 1997).

Heywood, A. 'Nationalism', in A. Heywood, Political Ideas and Concepts: An Introduction (Macmillan, 1994), pp. 152-85.

Heywood, A. 'Nations and Nationalism', in A. Heywood, POLITICS (Macmillan, 1997), pp. 103-19.

Hobsbawm, E. Nations and Nationalism since 1780 (Cambridge University Press, 1990).

Jay, R. 'Nationalism', in Robert Eccleshall et al., Political Ideologies: An Introduction (Routledge, 1994), pp. 153-84.

Kedourie, E. Nationalism (Hutchinson, 1985).

Purnell, R. 'The Notion of the Nation: Some Images and Myths', in R. Purnell, The

Society of States: An Introduction to International Politics (Weidenfeld and Nicolson, 1973), pp. 110-27.

Smith, A. The Ethnic Origins of Nations (Blackwell, 1986).

\section{SAMPLE QUESTIONS}

1 To what extent is the nation the fundamental unit of human organisation?

2 What are the main characteristics of nationhood? Do all nations have all of these characteristics?

3 How recent is the concept of the 'nation'?

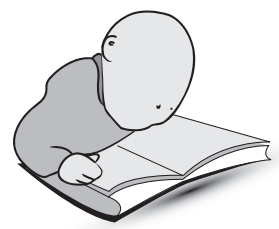

4 How far have such developments as globalisation and the creation of supranational entities like the European Union rendered the notion of the nation-state obsolete?

5 Is Britain a nation? 